\title{
Mobile Wireless Technology and Its Use in Lecture Room Environment: An Observation in Malaysian Institutes of Higher Learning
}

\author{
Vimala Balakrishnan and Gan Chin Lay
}

\begin{abstract}
The use of Mobile Wireless Technologies (MWT) such as mobile phones, tablets and laptops are widespread. Despite their advantages such as portability and speed, their use in the field of education is under-researched in Malaysia. This study was conducted with the main aim of exploring the use of (or rather the lack of) MWT during lectures in higher learning institutions. Non-participatory observations were conducted in four lecture sessions. Results clearly showed that no MWT tools were used during the lectures, and there are almost no interactions between students and lecturers despite the huge number of more than 50 students in the class. A hypothetical framework was then developed based on these findings and supported by related theories. Future work will aim to test and validate this framework by administering interviews and surveys with students and academicians in the country.
\end{abstract}

$\begin{array}{cccc}\text { Index } & \text { Terms-Higher } \\ \text { mobile } & \text { wireless } & \begin{array}{c}\text { learning institutions, } \\ \text { technology, }\end{array} & \begin{array}{c}\text { interaction, } \\ \text { observation, }\end{array}\end{array}$ students-academicians.

\section{INTRODUCTION}

Studies have been conducted to harness technological tools to enable interactivity in schools and tertiary institutions. Technological tools, such as a response system is believed to be able to raise students' participations and engagements in class. The recent explosion of Mobile Wireless Technology (MWT) brings much needed convenience and improves our ability to communicate whenever we want. In the higher education sector, MWT have made its impact and is fast being utilized by students and academicians. The myriad advantages of MWT such as mobility, simplicity and speed, etc. have resulted in it being a valuable tool in higher education [1].

Despite the many advantages of MWT and its high proliferation in the country, the use of MWT in higher learning institutions is under-researched. This study is therefore undertaken to explore the use of MWT during lecture sessions in higher learning institutions. The aim of this paper is twofold: 1) to explore the use of MWT in lecture rooms, and 2) to design a framework based on the observation results.

The remainder of the paper is organized as follows: The next section discusses the background studies conducted in MWT and education. This is followed by the research

Manuscript received April 5, 2013; revised July 17, 2013.

The authors are with the Faculty of Computer Science and Information Systems, University of Malaya, Kuala Lumpur, Malaysia (e-mail: vimala.balakrishnan@um.edu.my,gan.chin.lay@mmu.edu.my). methodology which delves into the observations. The results are presented next, followed by the development of the hypothetical framework. The future work concludes the paper.

\section{BACKGROUND STUDY}

Studies have indicated that the use of computers and technology is an integral part of the education process to improve learning [1]-[3]. It is however, interesting to note that the findings on the use of MWT during lectures are mixed. On the positive note, the use of MWTs were found to enable students' to send their feedbacks to their teachers [4], enhance interactivity and promote higher levels of learning attention [5] and enhance interaction amongst students and between students and lecturers [6].

On the other hand, the use of MWTs such as laptops during lectures resulted in students spending substantial amount of time multitasking, which may negatively affect students' learning [7]. Moreover, disruption activities, such as instant messaging and web surfing also create problems when laptops were allowed to be used during lectures [8].

In recent years, the proliferation of newer MWTs like tablets and iPad has brought significant changes for higher education. The Pearson Foundation found tablets ownership in college and college-bound students has tripled in just a year, and that $90 \%$ of the students who own tablets viewed such devices as valuable for educational purposes [9]. Colleges and universities have begun experimentations to integrate tablets and iPad in classrooms. In 2010, Seton University announced that it will start distributing iPad to all its full-time students. However, adoption of such technology by students and academicians in higher education does not translate to quality educational experience. Keyboard typing on the iPad screens using fingertip is deemed to be inconvenient and slows down typing speed [11].

\section{RESEARCH METHODOLOGY}

Non-participatory observations of large lectures (i.e. more than 50 students) were conducted at two local universities, covering four different subjects from science (Mathematics, Multimedia and Programming) and non-science (e-commerce) domains. These courses were for the undergraduate studies in the universities. Table I below provides the details.

The date, time and locations for each lecture observation were made in advance. The observations were also recorded, 
through which field notes were written down on significant occurrences during the observed lectures, such as the observed drawbacks of large lectures and the nature of students-lecturer interactions. Each observed lecture was approximately two hours. The recorded observations were replayed twice to confirm the observation field notes as well as to ensure crucial incidences were noted down.

TABLE I: OBSERVATION SUBJECTS

\begin{tabular}{clcc}
\hline \hline Lecture & Subject & Students present & Students absent \\
\hline 1 & Mathematics & 62 & 6 \\
2 & Multimedia & 116 & 5 \\
3 & Programming & 65 & 4 \\
4 & E-Commerce & 112 & 15 \\
\hline \hline
\end{tabular}

\section{IV.OBSERVATION RESULTS}

Table II (see next page) presents the overall outcomes of the observations. We present the main results in three categories as follows:

\section{A. Lecture Methods}

The main methods in lecture deliveries were the use of PowerPoint slides, and also the conventional white board and marker pens. This is probably due to the nature of the subjects themselves, whereby technical subjects such as Mathematics and Programming require the lecturers to further elaborate examples or points on the whiteboards.

\section{B. Lecturer Interaction with Students}

None of the lecturers were found to use any form of MWT during their lectures to facilitate interactions with their students. General face-to-face communication was used to gauge students' level of understanding, however, class discussions were not observed for all the lectures. This is probably due to the time limitation whereby the lecturers have approximately two hours to complete their syllabus for the day. Additionally, the large number of students in the classes also may have prohibited the discussions to be conducted during the lecture hours. Feedback elicitations were also not very satisfactory, with the majority of the responses coming from the front-row students. We believe self-esteem plays an important role here in which students who are confident generally are more forthcoming in responding. Additionally, probably the culture may also be one of the reasons for this scenario. Asians are generally not very vocal in voicing out their opinions or uncertainties in a public environment.

\section{Students Interaction with Lecturer}

The observation on the students' initiatives to communicate with the lecturer revealed the majority of the students to be quite, despite the large number of students in the lectures. Similarities were observed for two lectures whereby only very few students seated in the front rows made attempts in interacting with the lecturers. As for Programming and E-commerce, none of the students were found to have interacted with the lecturers.

In summary, we noted that interactions between students and lecturers need a lot of improvement. Although culture may affect the way one acts, we believe the use of MWT during lectures may improve students and lecturers interactions with each other. This needs to be further tested, therefore the next section describes the hypothetical framework proposed based on the observation results and also some existing models.

\section{HYPOTHETICAL FRAMEWORK}

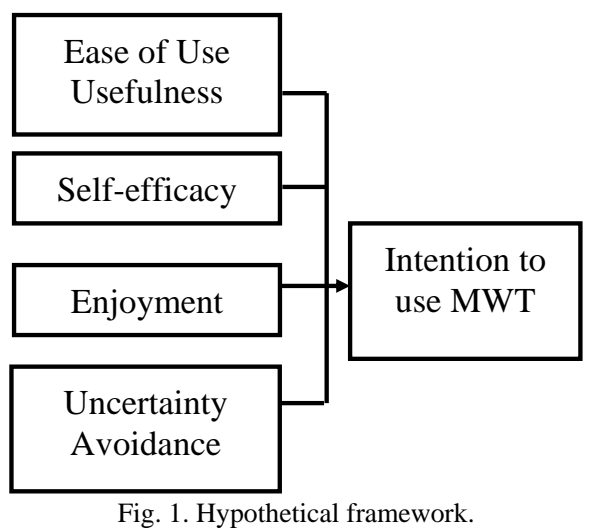

Fig. 1 above depicts the proposed framework to measure the intention to use MWT (dependent variable). Five main independent variables were identified from various theories and models. They are as follows:

Technology Acceptance Model (TAM): This model is based on perceived usefulness (the degree in which one believes that using an information system will improve productivity) and perceived ease of use (the degree in which one believes using an information system will require minimal effort) [12]. TAM has been used in various studies, such as, in assessing users' acceptance of email and computer software [13].

Motivational Model: This model dictates that intrinsic motivations come from an individual's sense of enjoyment in performing a task, without the need for reinforcements. Therefore, it is believed that when one enjoys using MWT, then he or she will be encouraged to use the technology more.

Social Cognitive Theory (SCT): SCT attempts to explain human behavior by placing importance on self-efficacy as a direct determinant of a person's behavior. Therefore, self-efficacy can be used to measure the personal confidence a person has in his or her own skills to use and interact with an instructor using MWT during lectures [14].

Hofstede's Dimensions of Culture: One of the Hofstede's dimensions that may be of particular interest in the study of technology acceptance model is uncertainty avoidance which refers to "the degree to which the members of a society feel uncomfortable with uncertainty and ambiguity" [15]. We believe that when a person is uncertain about the use of MWT, he or she will avoid using it.

\section{FUTURE WORK}

The observations revealed that interaction between students and lecturers need much improvement. Based on these findings and related theories and models, we proposed a hypothetical framework to measure the intention to use MWT during lectures. Therefore, the next stage of the study would be to validate this model. This will be accomplished 
by conducting interviews and questionnaire surveys involving lecturers and students in higher learning institutions in the country. It is believed that the results of the study may encourage academicians and students to use more technological tools during lectures.

TABLE II: LECTURE OBSERVATION

\begin{tabular}{|c|c|c|c|c|}
\hline & Lecture 1 & Lecture 2 & Lecture 3 & Lecture 4 \\
\hline \multicolumn{5}{|c|}{$\begin{array}{l}\text { Lecture methods: Observer focused on the general pacing of the lecture, techniques used by the lecturer in her presentation, types of learning activities } \\
\text { conducted and the use of instructional aids or tools }\end{array}$} \\
\hline $\begin{array}{l}\text { 1. Pacing and } \\
\text { presentation method }\end{array}$ & $\begin{array}{l}\text { Satisfactory. Mathematical } \\
\text { questions written down on the } \\
\text { whiteboard and students need } \\
\text { to complete the questions. } \\
\text { Observed only students in } \\
\text { front seem to have finished } \\
\text { the questions given. After the } \\
\text { allocated time, solutions were } \\
\text { given and explained by the } \\
\text { lecturer. }\end{array}$ & $\begin{array}{l}\text { Satisfactory. Lecture was } \\
\text { conducted using PowerPoint } \\
\text { slides. After each slides, } \\
\text { lecture will pause before } \\
\text { continuing to the next slide. }\end{array}$ & $\begin{array}{l}\text { Not satisfactory. Lecture in } \\
\text { the form of examples } \\
\text { driven, written on the white } \\
\text { board and students were } \\
\text { given time to copy. } \\
\text { Observed that insufficient } \\
\text { time was given and some } \\
\text { students were struggling to } \\
\text { finish copying down the } \\
\text { examples. }\end{array}$ & $\begin{array}{l}\text { Not satisfactory. } \\
\text { Lecture was } \\
\text { conducted using } \\
\text { PowerPoint slides. } \\
\text { Each slide follows } \\
\text { one another. Only } \\
\text { intermittent pause for } \\
\text { questions were } \\
\text { observed. }\end{array}$ \\
\hline 2. Learning activities & $\begin{array}{l}\text { Not observed. Mathematical } \\
\text { questions were written down } \\
\text { on the whiteboard and } \\
\text { students need to complete the } \\
\text { questions. Observed only } \\
\text { students in front seem to have } \\
\text { finished the questions given. } \\
\text { After the allocated time, } \\
\text { solutions were given and } \\
\text { explained by the lecturer. }\end{array}$ & $\begin{array}{l}\text { Not observed. A question } \\
\text { was written on the white } \\
\text { board. Students were given } \\
\text { time to solve the problem } \\
\text { after which volunteers were } \\
\text { elicited. Students seated in } \\
\text { front volunteered to write the } \\
\text { answer on the white board. } \\
\text { Discussion ensued. }\end{array}$ & $\begin{array}{l}\text { Not observed. } \\
\text { Programming questions } \\
\text { were fielded, students } \\
\text { given time to attempt and } \\
\text { explanation followed. }\end{array}$ & $\begin{array}{l}\text { Not observed. None } \\
\text { were given. }\end{array}$ \\
\hline $\begin{array}{l}\text { 3. Technological/ } \\
\text { instructional tools }\end{array}$ & $\begin{array}{l}\text { Not observed. Verbal lecture } \\
\text { delivery using the whiteboard } \\
\text { and marker pen only. }\end{array}$ & $\begin{array}{l}\text { PC provided in the lecture } \\
\text { hall, projector and } \\
\text { PowerPoint software. }\end{array}$ & $\begin{array}{l}\text { Not observed. Verbal } \\
\text { lecture delivery using the } \\
\text { whiteboard and marker pen } \\
\text { only. }\end{array}$ & $\begin{array}{l}\text { PC provided in the } \\
\text { lecture hall, projector } \\
\text { and PowerPoint } \\
\text { software }\end{array}$ \\
\hline \multicolumn{5}{|c|}{$\begin{array}{l}\text { Lecturer interaction with students: Focused was on the lecturer initiatives to encourage communication with students, prompting for feedbacks and responses } \\
\text { to students' enquiries. }\end{array}$} \\
\hline $\begin{array}{l}\text { 1. Prompt student } \\
\text { feedback to gauge } \\
\text { student } \\
\text { understanding. }\end{array}$ & $\begin{array}{l}\text { Satisfactory. After solutions } \\
\text { were discussed, students } \\
\text { understanding were enquired. } \\
\text { Some students in front } \\
\text { requested for additional } \\
\text { clarifications. Lecturer will } \\
\text { then repeat the explanation. }\end{array}$ & $\begin{array}{l}\text { Satisfactory. After some } \\
\text { slides, students were prompt. } \\
\text { Students seated in front were } \\
\text { seen giving some sort of } \\
\text { feedback or confirmation. } \\
\text { Some students were seen } \\
\text { nodding their heads. }\end{array}$ & $\begin{array}{l}\text { Satisfactory. After each } \\
\text { example, students were } \\
\text { prompt. Students were } \\
\text { generally not responsive. }\end{array}$ & $\begin{array}{l}\text { Need improvement. } \\
\text { Lack of initiative to } \\
\text { interact with students. }\end{array}$ \\
\hline $\begin{array}{l}\text { 2. Encourage class } \\
\text { discussions. }\end{array}$ & Not observed. & Not observed. & Not observed. & Not observed. \\
\hline $\begin{array}{ll}\text { 3. } & \text { Interact with all } \\
& \text { students fairly and } \\
& \text { impartially. }\end{array}$ & $\begin{array}{l}\text { Need improvement. } \\
\text { Interaction seems to center on } \\
\text { the students seated at the first } \\
\text { few rows. Partiality observed } \\
\text { towards front students. }\end{array}$ & $\begin{array}{l}\text { Satisfactory. The lecturer did } \\
\text { not singled out any students } \\
\text { during prompting. She } \\
\text { looked at the entire class in } \\
\text { general when enquiring. } \\
\text { Majority of the } \\
\text { communication took place at } \\
\text { the front of the classroom, }\end{array}$ & $\begin{array}{l}\text { Satisfactory. Lecturer } \\
\text { looked at the whole class in } \\
\text { general when interacting to } \\
\text { get students' feedback. } \\
\text { Students were not } \\
\text { responsive. }\end{array}$ & Not observed. \\
\hline $\begin{array}{l}\text { 4. Demonstrate } \\
\text { awareness when } \\
\text { students require } \\
\text { further clarification } \\
\text { and responds to } \\
\text { students' questions } \\
\text { and comments. }\end{array}$ & $\begin{array}{l}\text { Satisfactory. Lecturer } \\
\text { demonstrated awareness } \\
\text { when students fielded request } \\
\text { for further clarification. Took } \\
\text { place in front of classroom. } \\
\text { Students seated at the back } \\
\text { were passive. }\end{array}$ & $\begin{array}{l}\text { Not observed. Students did } \\
\text { not field any questions, only } \\
\text { confirmation when asked } \\
\text { whether they understood the } \\
\text { lecturer's explanation. }\end{array}$ & $\begin{array}{l}\text { Not observed. Students } \\
\text { were unresponsive and } \\
\text { none asked questions. }\end{array}$ & $\begin{array}{l}\text { Not observed. } \\
\text { Students were } \\
\text { unresponsive and } \\
\text { none asked questions. }\end{array}$ \\
\hline \multicolumn{5}{|c|}{ Students' interaction with lecturer: The observer focused on the students' initiatives to communicate with the lecturer. } \\
\hline $\begin{array}{l}\text { Demonstrate } \\
\text { attentiveness during } \\
\text { lecture and show } \\
\text { awareness when } \\
\text { lecturer prompts for } \\
\text { feedback. }\end{array}$ & $\begin{array}{l}\text { Need improvement. Only } \\
\text { students seated in first few } \\
\text { rows. Some students seated in } \\
\text { the back were seen chatting } \\
\text { and using their phones. }\end{array}$ & $\begin{array}{l}\text { Need improvement. Only } \\
\text { students in front provided } \\
\text { some feedback, like nodding } \\
\text { their heads or saying a } \\
\text { confirmation yes when } \\
\text { lecturer prompts them. }\end{array}$ & $\begin{array}{l}\text { Not observed. Students } \\
\text { were busy copying down } \\
\text { the notes. }\end{array}$ & $\begin{array}{l}\text { Not observed. Appear } \\
\text { nonchalant and } \\
\text { uninterested in the } \\
\text { subject matter. }\end{array}$ \\
\hline $\begin{array}{l}\text { 2. Are responsive to } \\
\text { lecturers' enquiries / } \\
\text { actively ask } \\
\text { questions. }\end{array}$ & $\begin{array}{l}\text { Need improvement. Only } \\
\text { students seated in front } \\
\text { responded. }\end{array}$ & $\begin{array}{l}\text { Need improvement. Only } \\
\text { students seated in front } \\
\text { responded. }\end{array}$ & $\begin{array}{l}\text { Not observed. Students } \\
\text { were unresponsive and } \\
\text { none asked questions. }\end{array}$ & $\begin{array}{l}\text { Not observed. None } \\
\text { of the students were } \\
\text { responsive or asked } \\
\text { any form of questions. }\end{array}$ \\
\hline
\end{tabular}




\section{ACKNOWLEDGMENT}

This study is supported by Flagship Grant (FL004-2012).

\section{REFERENCES}

[1] S. H. Kim, C. Mims, and K. P. Holmes, "An introduction to current trends and benefits of mobile wireless technology use in higher education," Association for the Advancement of Computing in Education Journal, vol. 14, pp. 77-100, 2006.

[2] N. Jones and A. M. S. Lau, "Blending learning: Widening participation in higher education," Innovations in Educational and Teaching International, vol. 47, pp. 405-416, 2010.

[3] T. Lindroth and M. Bergquist, "Laptopers in an educational practice: Promoting the personal learning situation," Computers and Education, vol. 54, no. 2, pp. 311-320, 2010.

[4] J. L. Fitch, "Student feedback in the college classroom: A technology solution," Educational Technology Research and Development, vol. 52 , no. 1, pp. 71-81, 2004.

[5] A. Wessels, S. Fries, H. Horz, N. Scheele, and W. Effelsberg, "Interactive lectures: Effective teaching and learning in lectures using wireless networks," Computers in Human Behavior, vol. 23, no. 5, pp. $2524-2537,2007$

[6] M. Barak, A. Lipson, and S. Lerman, "Wireless laptops as means for promoting active learning in large lecture halls," Journal of Research on Technology in Education, vol. 38, no. 3, pp. 245-263, 2006.

[7] C. B. Fried, "In-Class laptop use and its effects on student learning," Computers and Education, vol. 50, no. 3, pp. 906-914, 2008.

[8] R. H. Kay and S. Lauricella, "Exploring the benefits and challenges of using laptop computers in higher education classrooms: A formative analysis," Canadian Journal of Learning and Technology, vol. 37, no. 1, pp. 1-18, 2011.

[9] Pearson Foundation Survey on Students and Tablets. [Online]. Available:

http://www.pearsonfoundation.org/downloads/PF_Tablet_Survey_Su mmary_2012.pdf
[10] R. Reisinger. Pa. university to give all students iPads. [Online]. Available: http://news.cnet.com/8301-13506_3-10471690-17.html

[11] B. Weider, "iPads could hinder teaching, professors say," Chronicle of Higher Education, vol. 57, no. 28, pp. A22-A23, 2011.

[12] F. D. Davis, "Perceived usefulness, perceived ease of use, and user acceptance of information technology," MIS Quarterly, vol.13, no. 3, pp. 319-340, 1989.

[13] D. Adams, R. Nelson, and P. Todd, "Perceived usefulness, ease of use and usage of information technology: A replication," MIS Quarterly, vol. 16 , no. 2 , pp. 227-247, 1992.

[14] G. Hofstede, G. J. Hofstede, and M. Minkov, Cultures and oganizations: Software of the mind, 3rd ed., New York: McGraw-Hill USA.

[15] H. Holden and R. Rada, "Understanding the influence of perceived usability and technology self-efficacy on teachers' technology acceptance," Journal of Research on Technology in Education, vol. 43 , no. 4, pp. 343-367, 2011

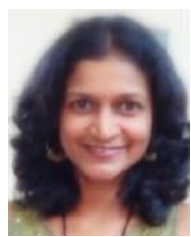

V. Balakrishnan received her $\mathrm{PhD}$ in the field of Ergonomics in 2009 from Multimedia University, Malaysia. Both her Masters and Bachelor degrees were from University of Science, Malaysia. She is currently affiliated with the Faculty of Computer Science and Information Technology, University of Malaya as a Senior Lecturer. Most of her research works are in the field of data engineering, opinion mining, information retrieval and health informatics. Dr. Balakrishnan is also a member of the Medical Research Support (Medicres) group and Global Science and Technology Forum.

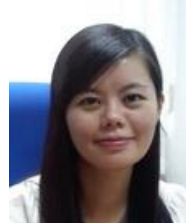

C. L. Gan is a lecturer at Multimedia University, Malacca, Malaysia. She is currently pursuing her $\mathrm{PhD}$ at the Faculty of Computer Science and Information Technology, University of Malaya. Her doctoral dissertation is on the integration of mobile wireless technology in higher learning institutions 